\title{
Wealth Shocks and Macroeconomic Dynamics
}

\author{
Daniel Cooper and Karen Dynan
}

\begin{abstract}
:
The effect of wealth on consumption is an issue of longstanding interest to economists. Analysts believe that fluctuations in household wealth have driven major swings in economic activity. This paper considers so-called wealth effects - the impact of changes in wealth on household consumption and the overall macroeconomy. There is an extensive existing literature on wealth effects, but there are also many unanswered issues and questions. This paper reviews the important issues regarding the role wealth plays in the macroeconomy and argues that there is a need for much more wealth effect research as well as better data sources for conducting such analysis.
\end{abstract}

\section{JEL Classification: E21}

Keywords: housing wealth, financial wealth, wealth effects, consumption, borrowing constraints, saving, household debt, deleveraging

Daniel H. Cooper is a senior economist in the research department at the Federal Reserve Bank of Boston. His e-mail address is daniel.cooper@bos.frb.org. Karen Dynan is vice president, co-director of Economic Studies, and the Robert S. Kerr Senior Fellow at the Brookings Institution. Her e-mail address is kdynan@brookings.edu.

The authors thank Kevin Todd and Michael Corbett for helpful research assistance.

This paper presents preliminary analysis and results intended to stimulate discussion and critical comment. The views expressed herein are those of the authors and do not indicate concurrence by the Federal Reserve Bank of Boston, by the principals of the Board of Governors, or by the Federal Reserve System.

This paper, which may be revised, is available on the web site of the Federal Reserve Bank of Boston at http://www.bostonfed.org/economic/ppdp/index.htm.

This version: June 14, 2013 


\section{Introduction}

The effect of wealth on consumption is an issue of longstanding interest to economists. Since the mid-1990s the relationship has been particularly important from a policy perspective, as over the last two decades the U.S. economy experienced two major booms and busts in stock prices, as well as a dramatic run-up and reversal of home prices. Analysts believe that the resulting fluctuations in household wealth have driven major swings in economic activity. Indeed, the plunge in household wealth during the financial crisis is frequently cited as an important contributing factor to the unusually slow economic recovery from the Great Recession.

Against this backdrop, it is perhaps not surprising that a great deal of empirical research over the last two decades has focused on so-called wealth effects - the impact of changes in wealth on household consumption and the overall macroeconomy. Such studies have used different types of data to examine the relationship between wealth and household spending, including macroeconomic time series, regional data, household survey results, and credit records. Despite this attention from the research community, many important questions about wealth effects remain unanswered. We review these questions and argue that there is a pressing need for more research in the area as well as a need to develop better data sources for such research.

\section{Background}

The swings in U.S. household wealth over the last two decades began with a run-up in stock prices in the late 1990s, as shown in Figure 1, that was driven in large part by optimism over the potential for new technologies to raise the productivity of U.S. businesses. Market confidence collapsed in early 2000, and stock prices subsequently retreated as the U.S. economy experienced a mild recession. By mid-2003, employment conditions began to show decided improvements amid robust economic growth, and the United States thereafter saw several years of rapidly rising stock and home prices.

Unfortunately, the prosperity proved to be transitory. Home prices, which had risen well above the levels justified by fundamentals, began to edge down in 2006 and were sharply falling by 2007. Delinquency rates on mortgages rose, starting with so-called affordable mortgages, many of which were fundamentally unsustainable in the absence of continued home price appreciation. The ensuing rise in defaults led to a tightening of credit conditions, further investor losses, and, ultimately, the most severe financial crisis and economic downturn in the United 
States since the Great Depression. By early 2009, the value of stocks held by households was down roughly 50 percent from its peak, and the value of real estate owned by households was down roughly 25 percent.

The evolution of U.S. household wealth clearly shows the imprint of these dramatic movements in asset prices, as shown in Figure 2. The stock price bubble of the late 1990s propelled the aggregate ratio of household wealth to disposable personal income from less than 5

to 6.2 at its peak at the turn of the century. After taking back most of these gains in the early 2000s, the ratio shot up again during the housing boom, reaching 6.5 in 2006 before tumbling to its lowest level in about fifteen years. Since this low point in early 2009, the recovery in stock prices, along with the modest recent home price gains, have returned the household wealth-toincome ratio to about its average level since the mid-1990s.

According to conventional wisdom, these swings in household wealth have been important drivers of economic activity in the United States. Policy-related discussions often reference the relationship between household wealth and consumption. For example, in its February 1996 Monetary Policy Report to Congress the Federal Reserve noted: "In the household sector, the accumulation of financial wealth brought on by the rise in the stock market has provided the wherewithal for increases in consumption greater than would otherwise have been expectedcountering the potential negative influences of more burdensome levels of consumer debt” (p. 286). In a 2002 speech, then Federal Reserve Governor Edward Gramlich remarked that "the link between aggregate household wealth and spending has remained one of the sturdier empirical relationships in macroeconomics." In a section focusing on job losses and the financial crisis, the 2013 Economic Report of the President stated that “A total of \$16 trillion in wealth was erased by the financial and housing crisis, causing families to pull back on spending plans, reduce personal debt and increase savings, in turn leading companies to cut back hiring, lay off valued employees, and halt investment plans." The high level of attention given by policymakers to household wealth underscores the importance of understanding as much as possible about its relationship to consumption.

\section{Estimating Wealth Effects Using Macro Data: Basic Results and Limitations}

Standard economic theory offers a framework for thinking about wealth effects. According to the permanent income hypothesis, households consume a constant fraction of the present discounted 
value of their lifetime resources. Changes in wealth that permanently alter households' resources therefore should cause consumption to change.

This posited relationship is consistent with the strong positive correlation seen when the aggregate "consumption rate” (consumption as a share of disposable personal income) is plotted against the ratio of aggregate household wealth to disposable personal income, as seen in Figure 3. More formal modeling of the relationship between these macroeconomic series has produced estimates of the timing and magnitude of the wealth effect. Davis and Palumbo (2001) present an analysis based on typical forecasting models and conclude that consumer spending rises by between 3 and 6 cents for every additional dollar of wealth, with the effect occurring gradually over a period of several years (see also, Lettau and Ludvigson 2004).

While macroeconometric models provide useful guidance on the average historical relationship between aggregate consumption and wealth, these models also have limitations. In particular, the degree to which the models are useful for forecasting aggregate consumption dynamics or uncovering key economic relationships depends on the degree to which household behavior is homogeneous as well as the degree to which changes to the economic environment are distributed evenly and consistently over time. In practice, these theoretical conditions are not met: the actual economy is characterized by heterogeneity that is not consistent over time.

In the existing wealth effects literature, much attention has focused on credit constraints as a potential source of heterogeneity in how different households respond to changes in wealth. In particular, households that are consuming at a suboptimal level because they cannot borrow as much as they desire should have a particularly powerful consumption response to wealth gains (at least to the extent that those gains can be liquefied). Because lower-income households are more likely to face credit constraints, this logic represents one justification for the concavity of the consumption function featured in models like Carroll, Slacalek, and Sommers (2012). Lehnert (2004) estimated higher propensities to consume out of housing wealth for younger U.S. households than their somewhat older counterparts, arguing that the former group was the most likely to be credit constrained, and Campbell and Cocco (2007) followed up with a similar analysis of U.K. data. In more recent work, Cooper (forthcoming) used several alternative approaches to show that borrowing constraints heighten the relationship between consumption and housing wealth in U.S. household-level data. Finally, using spending and balance sheet data at the regional level, Mian, Rao, and Sufi (2013) find significantly higher propensities to 
consume for poorer and more levered households-again, the groups most likely to be credit constrained. Although the precise results differ from paper to paper, the findings in these studies are strongly consistent with the view that housing wealth effects are larger for households that are more likely to be facing borrowing constraints (see also Bostic, Gabriel, and Painter, 2009, and Case, Quigley and Shiller, 2005, 2011, and 2013).

The geographic dispersion of the housing wealth movements of the last decade represents another possible source of heterogeneity in wealth effects. Figure 4 shows the wide dispersion of home price appreciation across states from 2002 to 2006. For the most part, the subsequent housing bust was similarly concentrated. This distribution should be relevant for the strength of the aggregate wealth effect given that different states have different demographic characteristics that should affect the response of consumption to wealth (for example, one might expect a stronger effect in states where people are in demographic groups more likely to be liquidity constrained).

These types of heterogeneity do not in and of themselves invalidate analyses of wealth effects based on macroeconomic models. If aggregate wealth changes always had the same distribution across people and space, then the estimated coefficients from the models-which essentially reflect the average historical relationship between wealth and consumption-would well capture the expected response to a new change in wealth. But, in fact, the distribution of aggregate wealth changes across different types of people is not consistent over time; it varies because of differences in the types of wealth held and also because the fraction of people having a certain trait (such as being borrowing constrained) can change. The spatial dispersion of wealth shocks also varies over time. For example, real house prices surged 39 percent in the Boston Metropolitan Statistical Area (MSA) between 1984 and 1986 as part of a coastal housing boom during that time. In comparison, real house price appreciation was only about 8.5 percent in the Chicago MSA and 4.3 percent in the Kansas City MSA over this same period.

\section{Key Unresolved Issues Regarding Wealth Effects}

The previous discussion of the limitations that the standard macroeconometric approach imposes when modeling wealth effects highlights the need to know much more about the underpinnings of wealth effects at the household level. In this section, we discuss the four outstanding questions 
that are most important from a policy perspective, reviewing where the literature currently stands and where more research would be helpful.

\section{A. Is Housing Wealth Really Wealth?}

The recent boom and bust in home prices has spurred interest in how housing wealth influences the macroeconomy, and, in particular, whether housing wealth has the same effect on households' spending decisions as financial wealth. To this point, Buiter (2010) and Flavin and Nakagawa (2008) both argue that housing wealth is not really wealth. The underlying intuition is that housing wealth differs from other household (financial) wealth because it serves both as an asset and as a consumption good. As a result, when home prices rise, the ownership (or rental) costs of housing increase.

Renters are unambiguously worse off when the cost of housing consumption increases because, for a given amount of income they must reduce their consumption of non-housing goods in order to offset the higher cost of their shelter. The impact of home price appreciation on homeowners is less clear, as higher housing costs require homeowners' to decrease their nonhousing consumption for a given amount of income, but there is an offset through the capital gain associated with higher home prices. If housing costs do not increase one-for-one with home price appreciation, then homeowners could be better off when house prices rise. Typically, though, economists think that housing costs and home prices move together so homeowners' true housing wealth gains may be small or nonexistent. Moreover, homeowners may have to reoptimize and downsize their housing stock in order to fully realize their gains for consumption purposes-something that many homeowners may not be willing to do, especially in the shortterm.

Housing wealth may, however, impact consumption indirectly through its role as borrowing collateral. When home prices rise, the value of homeowners' collateral increases, and they can borrow against their additional home equity to spend more on goods and services (including home improvements) and meet other financial needs. Previously constrained homeowners are therefore likely to increase their spending when house prices increase. In the data, this effect should show up as a positive relationship between housing wealth and consumption. 
Further, as Case, Quigley, and Shiller (2013) argue, there might be psychological reasons why homeowners may increase their consumption in response to housing appreciation. For instance, they may be responding to societal perceptions that housing gains make them better off or they may be myopic and failing to consider that if everyone in their area experiences similar housing gains they are not necessarily any better off.

Another consideration that should tend to raise the aggregate housing wealth effect on consumption relative to the financial wealth effect is that housing wealth is more widely distributed across households. Table 1 shows that roughly two-thirds of U.S. households own homes while only about half hold stocks (including stocks held indirectly through mutual funds, defined-contribution retirement plans, and the like). The data come from the Survey of Consumer Finances (SCF), weighted to be nationally representative. Because the SCF oversamples wealthy households who are the most likely to hold stocks, its data are viewed as being particularly accurate for these types of comparisons. In addition, the share of housing wealth in total wealth is much higher for lower-income homeowners than for higher-income homeowners, as shown in Table 2. Compared to higher income households, lower-income households are more likely to be credit constrained and myopic, so the higher housing wealth concentration in lower parts of the income distribution should tend to make the aggregate marginal propensity to consume out of housing wealth higher than the aggregate marginal propensity to consumer that is associated with financial wealth.

Taken together, these various considerations suggest that the housing wealth effect could be larger or smaller than the effect associated with financial wealth. As a result, the differential impact is largely an empirical question. Although this question has received much attention within the wealth effects literature during and after the recent housing boom and bust, consensus has yet to be reached.

Case, Quigley, and Shiller (2005) found relatively large housing wealth effects and relatively small financial wealth effects using state-level panel data. Bostic, Gabriel, and Painter (2009) found similar results using household-level data and, based on credit-record evidence on the amount of housing capital gains that were liquefied during the housing boom, Mian and Sufi (2011) also concluded that housing wealth effects are very large. In contrast, after paying particular attention to the borrowing collateral role of housing wealth Cooper (forthcoming) finds slightly larger financial wealth effects than housing wealth effects. De Bonis and Silvestrini 
(2012) also found larger financial asset effects than real (housing) wealth effects on consumption using a panel of OECD countries. Sierminska and Takhtamanova (2012) showed that the relative size of the financial wealth effect versus housing wealth effect depends on the country studied and that the within-country differences may be driven by certain age groups.

The empirical results regarding the relative sizes of the financial wealth and housing wealth effects are thus mixed. These differences matter for thinking about the interaction between household wealth and the macroeconomy because the vast majority of forecast models follow Thaler's (1990) assumption that assets are fungible and that money is money. More empirical work is therefore needed to determine whether assets are not fungible and if so, what is the mechanism causing one effect to matter more than another. Based on Hong Kong data, Gan (2010) argues that perhaps gains in housing wealth lower households' desired precautionary saving because housing equity becomes an additional (or larger) buffer against future income risk. This logic contrasts with previous behavioral arguments (see, for example, Levin 1998) suggesting that consumption should be more sensitive to liquid assets than illiquid assets.

If households indeed have different propensities to consume out of one type of wealth than another, accurate forecasting of macroeconomic growth will require taking account of differential movements in the various components of household wealth. Conventional consumption models typically include just total wealth rather than its individual pieces. This means that the coefficient on wealth reflects the average experience over time, which will, in turn, reflects the average historical "driver" of aggregate wealth movements that may be higher or lower than the propensity to consume out of a given component of wealth.

\section{B. The Underpinnings of Stock Market Wealth Effects}

Although one does not have to worry about stocks being consumption goods when thinking about the stock market wealth effect, the logic is not entirely straightforward for several reasons. First, rising stock prices require individuals who do not own stocks but intend to do so in the future (for example, younger households with plans to begin saving for retirement) to purchase them at a higher price. Second, some increases in stock prices reflect higher expected future dividends because of upward revisions to firms' productivity, while other increases reflect reductions in the rate at which future dividends are discounted. In the former case, stockholders 
are unambiguously better off, but in the latter case they are not because the discounted value of planned future consumption is also revised upward. Third, some recent evidence suggests that because of behavioral considerations individuals might respond anomalously to stock market gains realized in defined-contribution pension accounts. In particular, Choi, Laibson, Madrian, and Metrick (2009) find that individuals tend to raise their retirement plan contributions after experiencing good returns; if these higher contributions are funded by reduced consumption, one would see a wealth effect in the opposite direction from what standard theory predicts.

In the data, there is a strong positive relationship between aggregate consumption and aggregate stock prices. But, given the considerations above, some analysts have argued that this relationship may not stem from the direct effect of consumption on wealth but rather from a signaling channel. In particular, since stock prices tend to rise and fall with optimism about the economy, it may be the case that consumption is responding primarily to revisions to households' expectations about future wage growth.

The standard empirical approach to this question is to look at whether stockholders have a different response to stock price increases than nonstockholders - the existence of a direct wealth effect is supported by findings that the response of stockholders is more pronounced. Poterba and Samwick (1995) find stockholders' food consumption reacts more strongly to stock market movements than that of nonstockholders, and Dynan and Maki (2001) find a similar response for a broad measure of consumption. Maki and Palumbo (2001) create synthetic data on saving and capital gains for different cohorts of households during the 1990s and find that the largest declines in saving (and therefore the biggest increases in consumption) occurred for the groups most likely to hold stocks.

Much less work has been done on this question over the past decade, presumably because the focus of the empirical wealth effects literature has shifted largely to the housing area. However, Dynan (2010) finds preliminary evidence that incorporating more recent household-level data into analyses of the differential behavior of stockholders and nonstockholders considerably weakens the earlier results. Given that the dramatic swings in stock prices since the late 1990s offer much more opportunity for identification of the underpinnings of stock market wealth effect, more research should revisit the earlier findings. 


\section{C. Wealth Effects and the Liabilities Side of the Balance Sheet}

Wealth effects are typically viewed as stemming from movements in the prices of assets such as stocks and homes. However, a household's net worth is also a function of the debt that it holds. The U.S. economy's sluggish performance in recent years-combined with the high levels of household debt and leverage that emerged from the mortgage boom and bust-has drawn attention to the issue of whether debt is playing a special role holding down consumption. In such a case, macroeconomists would want to take account of debt-related developments in addition to looking at movements in overall wealth.

The theoretical case for household debt holding down consumption is not completely clear, as the traditional models used by economists suggest that debt does not exert an independent influence on consumption (although a positive and endogenous relationship would be expected because debt represents a way to finance spending that is spurred by other considerations). However, going beyond the simple models, a case can be made on several grounds that debt does impede consumer spending. First, some households may target a given level of debt relative to their income or assets; if the events of recent years increased these ratios (or lowered households' target ratios), one might expect these households to choose to pare back their consumption in order to pay down debt. Second, high-debt households may have become more worried about future credit availability, leading them to cut their consumption so as to increase their savings. Third, households whose current income is lower than their permanent income may have been forced to reduce their consumption because their high debt levels relative to income or assets prevented them from obtaining any further credit they may have needed to finance their desired spending.

Turning to the empirical literature, Cooper (2012) presents an analysis of aggregate data that concludes that consumption has not behaved particularly unusually given movements in household income and net worth. Yet, in household-level data, Dynan (2012) and Cooper (2012) both find that high debt had a negative impact on consumption growth during the Great Recession even after controlling for income, net worth, and other factors likely to affect spending. As Cooper (2012) highlights, this negative relationship existed prior to the Great

Recession, suggesting that recent period is not particularly unusual. Even so, debt could have had a larger recent impact on consumption since more households are burdened by high debt and leverage compared with earlier periods. In addition, Dynan and Edelberg (2013) found that high- 
debt households were more likely to report scaling back their consumption in 2009, again after controlling for other drivers of spending. Finally, as noted earlier, Mian, Rao, and Sufi (2013)'s analysis of regional data concluded that leverage helped amplify the negative wealth effect on consumption associated with declining house prices during the Great Recession.

The household-level empirical research on the relationship between debt and consumption is, as yet, limited. At best, it considers only the period through the Great Recession and does not directly speak to the economy’s weak performance during the recovery. Moreover, the standard errors in many of these studies are large. Finally, the emphasis has been on establishing the relationship rather than discerning why a relationship exists, an issue that is highly relevant to the discussion pertaining to what, if any, policies should be used to address the situation. These shortcomings suggest many promising avenues for further research.

More theoretical work on the connection between household debt and leverage and macroeconomic activity is also needed, a point emphasized by Cooper (2012). Some preliminary steps in this direction have been taken (see, for example, Eggertsson and Krugman 2012) but more work needs to be done to realistically characterize the complex linkages found in the actual economy.

\section{D. Has the Wealth Effect Changed over Time?}

As noted above, if the response of household spending to changes in wealth differs by type of wealth, then one should expect to see the strength of the aggregate wealth effect to be different depending on the underlying source of a given movement in aggregate household wealth. In this section, we discuss other reasons why the wealth effect-at both the aggregate and individual levels-may change over time.

To begin, the size of the aggregate wealth effect may have changed because of demographics. In principle, older households with shorter remaining life horizons over which to annuitize wealth changes should have a larger marginal propensity to consume out of wealth shocks than younger households. Of course, such age differences may depend on whether households' horizons actually do depend on their expected remaining lifespan-they might be muted if households take a dynastic view and intend to share their gains with their descendents. But, generally, this consideration implies that the aging of the baby boom generation should tend to increase the aggregate marginal propensity to consume. 
Financial innovation may have also changed the link between wealth and consumption. Starting around the early 1980s, technological advances and institutional developments (including regulatory and tax code changes) reduced credit constraints, increasing availability and lowering the cost of borrowing. But the effect of these changes on the size of the wealth effect is unclear. On the one hand, having fewer credit-constrained households might reduce the aggregate wealth effect since, as discussed above, the empirical evidence suggests that credit constraints tend to be associated with a stronger wealth effect. On the other hand, financial innovation made it easier and cheaper to realize home equity gains through home equity loans and cash-out refinancing transactions, such that homeowners still constrained could borrow more easily against housing capital gains. By itself, this trend should have tended to increase the aggregate wealth effect. Of course, in recent years, credit availability has swung in the other direction undoing some, though not all, of these changes.

On the asset side of the balance sheet, financial innovation has allowed more households to own stocks through vehicles such as mutual funds and 401(k)-like accounts. Although the ownership rate has been around 50 percent since 2000 (Table 1), it was only a little more than 30 percent in the late 1980s (Dynan 2009). As a result, more stock is held by lower-income households that likely have higher marginal propensities to consume. All else equal, this should have tended to increase the aggregate wealth effect, although the effect could be muted or even go the other way if households view their retirement accounts as "off limits" for consumption. Household spending could also fall, as discussed above, in the face of capital gains if households are "chasing returns.”

All told, many factors may have changed the aggregate wealth effect over time. Assessing the direction in which it has changed is difficult using aggregate data because of the small sample sizes. For example, recent research by Soss and Mo (2013), analysts at Credit Suisse, showed that the estimated wealth effects for both housing and financial wealth were smaller when postfinancial crisis data were used in the analysis, but the limited variation seen since the crisis (home prices were roughly flat and the stock market mostly trended upward) means that the authors could not effectively estimate separate coefficients for the different periods. However, researchers should be able to draw inferences on how the coefficients may have changed in response to these developments using household-level or regional data, where the price variation is much richer. 


\section{Data Challenges}

As has been discussed throughout this piece, macroeconomic data are not very useful for establishing the empirical relationship between wealth and consumption. The variation is limited, which hinders identification, particularly when relationships are changing over time and the determinants of consumption are inter-related.

Household-level datasets tend to be much richer in scope and have many data points such that there is much more opportunity for identification. Yet, they too have shortcomings. First, most household datasets do not have all of the elements needed for estimating consumption functions - a panel dimension, complete balance sheet information, broad measures of consumption, good income measures, and demographic information (which can proxy for preferences, risk of job loss, access to credit, and other things). Even when such information is available (as in the cases of the U.S. Panel Study on Income Dynamics and the U.S. Health and Retirement Survey), the data tend to be noisy because of recall error and other measurement problems, leading to imprecise estimates of key relationships. Household-level data are also not without identification issues, but these issues can be circumvented by, for instance, looking at effects across different groups of households. (See Cooper 2012 for more details).

Recently, researchers have turned to administrative records, such as data from credit bureaus or financial services companies. These datasets tend to be quite detailed and accurate in terms of the data the companies track and record, but they lack direct measures of household consumption, income, and total wealth. Innovative researchers such as Mian, Rao, and Sufi (2013) have aggregated these types of administrative records to the regional level and then combined them with regional information related to consumption, income, and wealth in order to do more complete analyses. This approach shows promise and should be explored more fully. However, identification with regional data may always be impaired because the set of covariates is simply not as rich as it would be in household survey data. For example, there is no data source in the United States that would offer complete information about wealth by region. An ideal solution might be to merge the less noisy administrative data on the available variables into household surveys in order to have the best of all worlds.

\section{Conclusion}


To date there has been much interesting research on and debate surrounding the influence of wealth shocks on macroeconomic dynamics. Much remains to be learned in this area. Understanding wealth effects is critical not only for forecasting consumption and broader economic growth well but also for gauging the risks to the economic outlook and setting appropriate macroeconomic policy. Such issues are particularly important during periods of substantially fluctuating asset prices.

We have identified a need to learn more about the underpinnings of wealth effects and how the effects might differ for different components of household wealth, including on the liabilities side of the balance sheet. On a related topic, more work is needed to understand how aggregate wealth effects may have changed (and still are changing) over time. The research has been limited to some extent by lack of good data sources, and, accordingly, some focus should be placed on ways we can improve existing datasets and create new ones. 


\section{References}

Buiter, Willem H. 2010. “Housing Wealth Isn’t Wealth.” Economics: The Open-Access, Open Assessment E-Journal 4, No. 2010-22. Available at http://dx.doi.org/10.5018/economics ejournal.ja.2010-22.

"Monetary Policy Report to the Congress”. 1996. (February 20). Federal Reserve Bulletin April 1996. Washington, DC: Board of Governors of the Federal Reserve System. Available at http://www.federalreserve.gov/pubs/bulletin/1996/496lead.pdf.

Bostic, Raphael, Stuart Gabriel, and Gary Painter. 2009. "Housing Wealth, Financial Wealth, And Consumption: New Evidence from Micro Data.” Regional Science and Urban Economics 39(1): 79-89.

Campbell, John Y., and João F. Cocco . 2007. "How Do House Prices Affect Consumption? Evidence from Micro Data.” Journal of Monetary Economics 54(3): 591-621.

Carroll, Christopher, Jiri Slacalek, and Martin Sommer. 2012. "Dissecting Saving Dynamics: Measuring Wealth, Precautionary, and Credit Effects. Working Paper No. 12/219. Washington, DC: International Monetary Fund. Available at http://www.imf.org/external/pubs/ft/wp/2012/wp12219.pdf.

Case, Karl E., John M. Quigley, and Robert J. Shiller. 2005. “Comparing Wealth Effects: The Stock Market versus the Housing Market.” The BE Journal of Macroeconomics 5(1): 1-32.

Case, Karl E., John M. Quigley, and Robert J. Shiller. 2011. "Wealth Effects Revisited 1978 -2009. Working Paper No.16848. Cambridge, MA: National Bureau of Economic Research.

Case, Karl E., John M. Quigley, and Robert J. Shiller. 2013. "Wealth Effects Revisited: 19752012.” Working Paper No. 18667. Cambridge, MA: National Bureau of Economic Research.

Choi, James J., David Laibson, Brigette C. Madrian, and Andrew Metrick. 2009. "Reinforcement Learning and Savings Behavior.” Journal of Finance 64(6): 2515-2534.

Cooper, Daniel H. Forthcoming. "House Price Fluctuations: The Role of Housing Wealth as Borrowing Collateral.” Review of Economics and Statistics.

Cooper, Daniel. 2012. "U.S. Household Deleveraging: What Do the Aggregate and HouseholdLevel Data Tell Us?” Public Policy Brief No. 12-2. Boston: Federal Reserve Bank of Boston. Available at http://www.bostonfed.org/economic/ppb/2012/ppb122.htm.

Davis, Morris A., and Michael G. Palumbo. 2001. “A Primer on the Economics and Time Series Econometrics of Wealth Effects.” Finance and Economics Discussion Series No. 2001-09. Washington, DC: Board of Governors of the Federal Reserve System. Available at www.federalreserve.gov/pubs/feds/2001/200109/200109abs.html. 
De Bonis, Riccardo, and Andrea Silvestrini. 2012. "The Effects of Financial and Real Wealth on Consumption: New Evidence from OECD Countries.” Applied Financial Economics 22(5): 409-425.

Dynan, Karen E., and Dean M. Maki. 2001. “Does Stock Market Wealth Matter for Consumption?” Finance and Economics Discussion Paper No. 2001-23. Washington, DC: Board of Governors of the Federal Reserve System. Available at http://www.federalreserve.gov/pubs/feds/2001/200123/200123pap.pdf.

Dynan, Karen E. 2009. "Changing Household Financial Opportunities and Economic Security.” Journal of Economic Perspectives 23(4): 49-68.

Dynan, Karen. 2010. "Wealth Effects and the Changing Economy.” Working Paper. Washington, DC: The Brookings Institution. Available at http://www.brookings.edu/ /media/research/files/papers/2010/5/14\%20wealth\%20effects\%20ch anging\%20economy\%20dynan/14\%20wealth\%20effects\%20changing\%20economy\%20dynan.p df.

Dynan, Karen. 2012. "Is a Household Debt Overhang Holding Back Consumption? Brookings Papers on Economic Activity 1 (Spring): 299-344.

Dynan, Karen, and Wendy Edelberg. 2013. "What’s Driving Deleveraging? Evidence from the 2007-2009 Survey of Consumer Finances.” Unpublished Manuscript.

Economic Report of the President. 2013. Washington, DC: U.S. Government Printing Office. Available at http://www.whitehouse.gov/sites/default/files/docs/erp2013/full_2013_economic_report_of_the president.pdf.

Eggertsson, Gauti, and Paul Krugman. 2012. "Debt, Deleveraging, and the Liquidity Trap: A Fisher-Minsky-Koo Approach.” Quarterly Journal of Economics 127(3): 1469-1513.

Flavin, Marjorie, and Shinobu Nakagawa. 2008. "A Model of Housing in the Presence of Adjustment Costs: A Structural Interpretation of Habit Persistence.” American Economic Review 98(1): 474-495.

Gan, Jie. 2010. "Housing Wealth and Consumption Growth: Evidence from a Large Panel of Households.” Review of Financial Studies 23(6): 2229-2267.

Gramlich, Edward M. 2002. "Consumption and the Wealth Effect: The United States and the United Kingdom.” Remarks before the International Bond Conference, London, United Kingdom, February 20, 2002. Available at http://www.federalreserve.gov/BoardDocs/Speeches/2002/20020220/. 
Lehnert, Andreas. 2004. “Housing, Consumption, and Credit Constraints.” Finance and Economics Discussion Series No. 2004-63. Washington, DC: Board of Governors of the Federal Reserve System.

Available at http://www.federalreserve.gov/pubs/feds/2004/200463/200463pap.pdf.

Lettau, Martin, and Syudney C. Ludvigson, S. 2004. "Understanding Trend and Cycle in Asset Values: Reevaluating the Wealth Effect on Consumption. American Economic Review 94(1): 276-299.

Levin, Laurence. 1998. “Are Assets Fungible? Testing the Behavioral Theory of Life-Cycle Savings.” Journal of Economic Behavior \& Organization 36(1): 59-83.

Maki, Dean M. and Michael G. Palumbo. 2001. "Disentangling the Wealth Effect: A Cohort Analysis of Household Saving in the 1990s.” Finance and Economics Discussion Series No. 2001-21. Washington, DC: Board of Governors of the Federal Reserve System. Available at http://www.federalreserve.gov/pubs/feds/2001/200121/200121abs.html.

Mian, Atif, and Amri Sufi. 2011. "House Prices, Home Equity-Based Borrowing, and the U.S. Household Leverage Crisis.” American Economic Review 101(5): 2132-2156.

Mian, Atif, Kamalesh Rao, and Amri Sufi. 2013. "Household Balance Sheets, Consumption, and the Economic Slump.” Chicago Booth Research Paper No. 13-42.

Poterba, James M., and Andrew A. Samwick. 1995. "Stock Ownership Patterns, Stock Market Fluctuations, and Consumption.” Brookings Papers on Economic Activity 26(2): 295-357.

Sierminska, Eva, and Yelena Takhtamanova. 2012. "Financial and Housing Wealth and Consumption Spending: Cross-Country and Age Group Comparisons.” Housing Studies 27(5): 685-719.

Soss, Neal, and Henry Mo. "Honey, I Shrunk the Wealth Effect.” 2013. US Economics Digest, February 13. New York: Credit Suisse. Available at https://doc.research-and analytics.csfb.com/docView?language=ENG\&format=PDF\&document_id=1009835261\&sour ce_id=emcmt\&serialid=8YGZy8sRLE7s8bPAqiwckJea9Oo1BMSdc81jhgkqNFI\%3d.

Thaler, Richard H. 1990. "Saving, Fungibility, and Mental Accounts.” Journal of Economic Perspectives 4(1): 193-205. 
Table 1: Ownership Rates by Type of Asset

\begin{tabular}{|c|c|c|}
\hline Year & Housing & Stocks \\
\hline 2001 & 66.9 & 52.3 \\
\hline 2004 & 68.4 & 50.3 \\
\hline 2007 & 67.9 & 53.2 \\
\hline 2010 & 64.6 & 49.9 \\
\hline
\end{tabular}

Source: Survey of Consumer Finances and authors’ calculations.

Notes: Table reports the percent of the population with wealth holding in housing and the stock market (including stocks held indirectly in 401(k)type retirement accounts). Results are weighted to be nationally representative.

Table 2: Housing Wealth Concentration by Income Quintile

\begin{tabular}{|c|r|r|r|r|r|}
\hline \multicolumn{7}{|c|}{ Income Quintile } \\
\hline Year & 1 & 2 & 3 & 4 & 5 \\
\hline 2001 & 65.0 & 41.9 & 32.7 & 22.3 & 11.4 \\
\hline 2004 & 73.3 & 51.3 & 37.7 & 28.3 & 11.1 \\
\hline 2007 & 69.9 & 49.4 & 41.7 & 27.3 & 11.4 \\
\hline 2010 & 71.0 & 48.3 & 37.6 & 26.3 & 13.6 \\
\hline
\end{tabular}

Source: Survey of Consumer Finances and authors’ calculations.

Notes: Table reports the median share of housing wealth as a percent of total wealth according to the Survey of Consumer Finances. " 1 " represents the lowest quintile of income in a given year and " 5 " represents the highest quintile. 
Figure 1: Stock Prices and House Prices

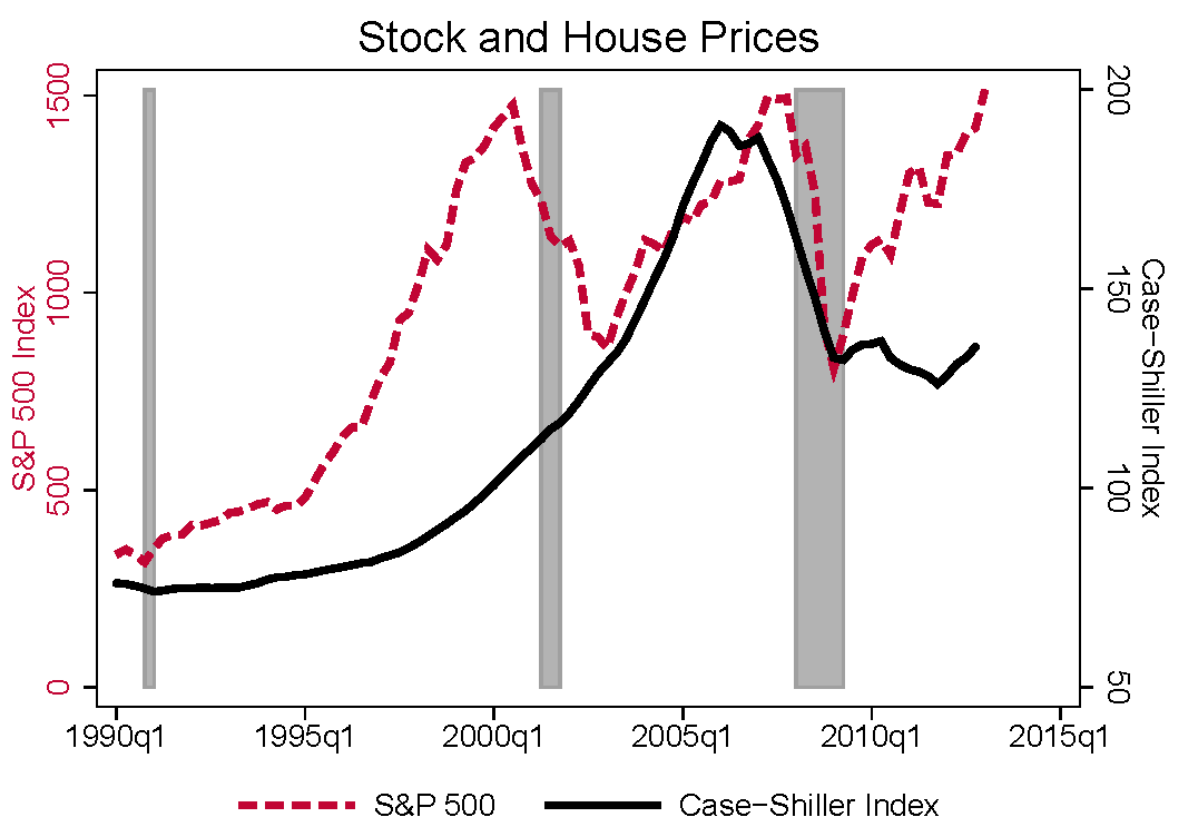

Source: Standard and Poor's, Wall Street Journal/ Haver Analytics

Figure 2: Net Worth-to-Income Ratio

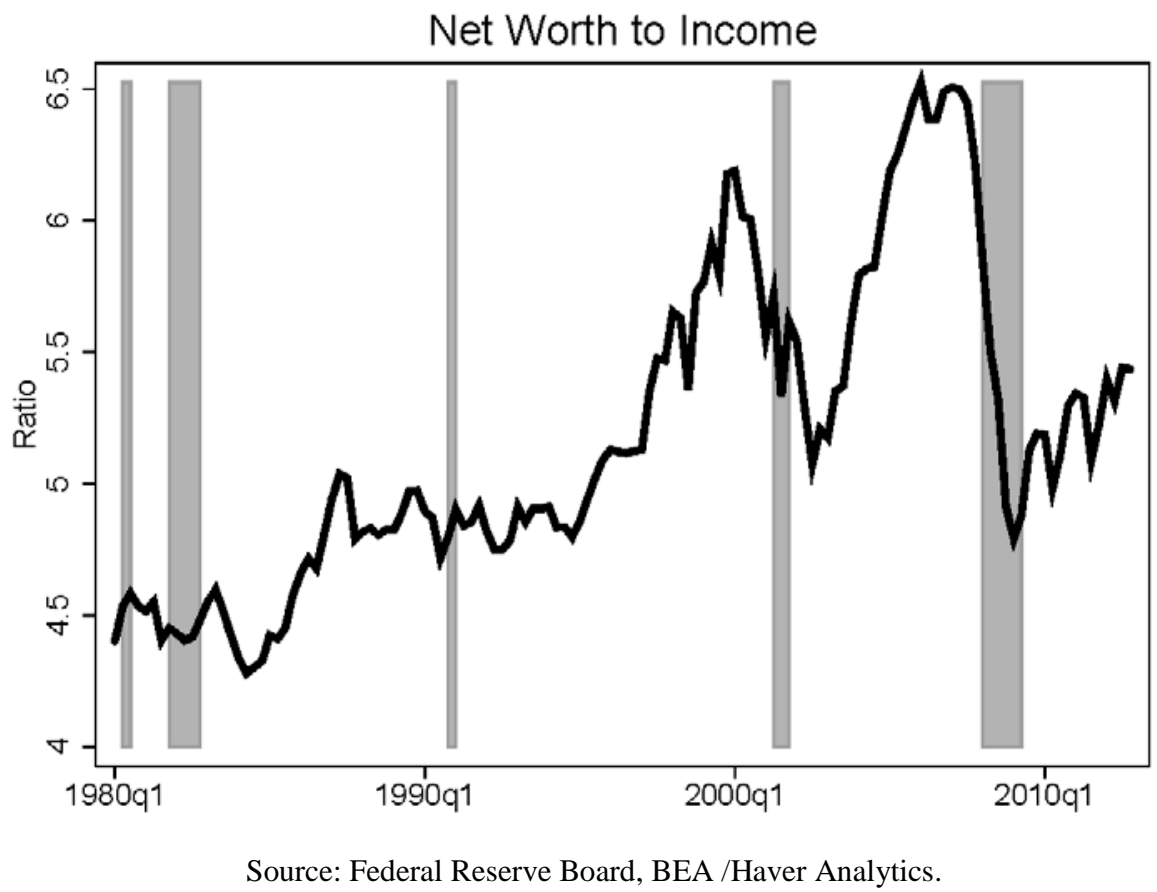


Figure 3: Consumption and Net Worth

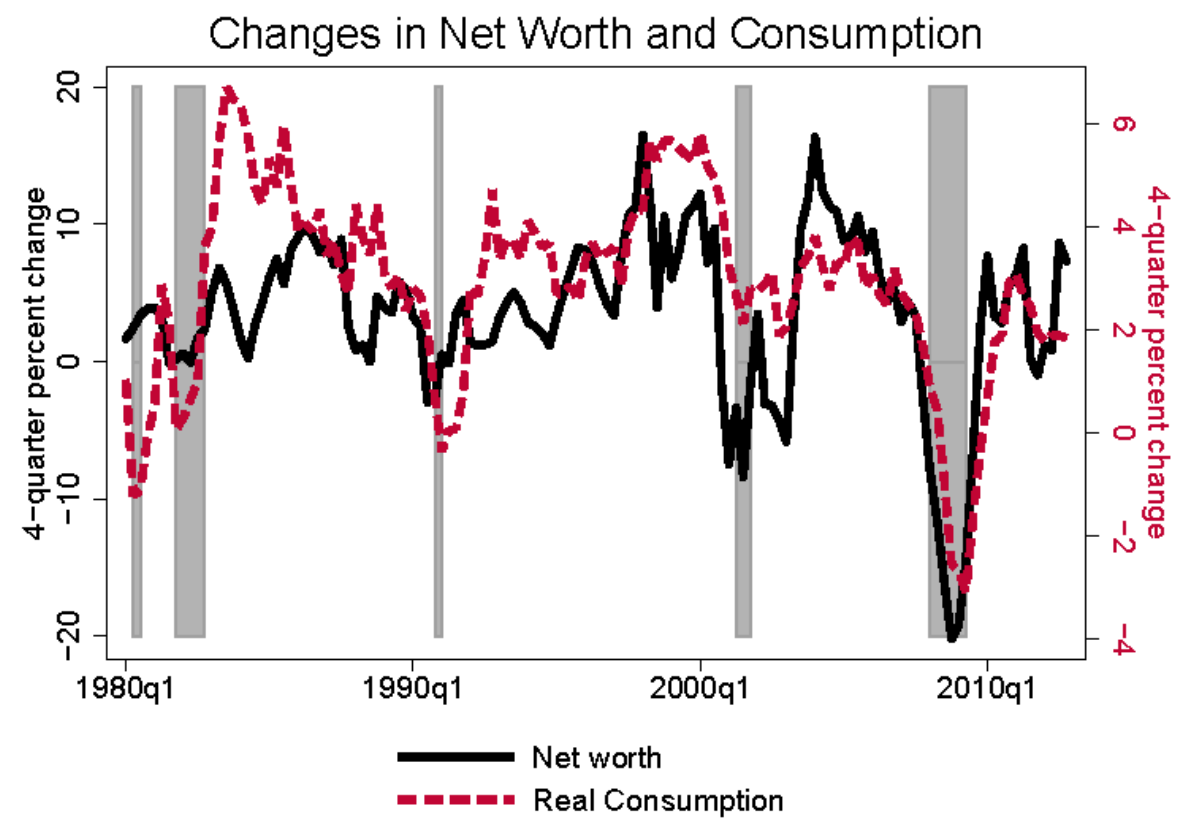

Source: Federal Reserve Board, BEA /Haver Analytics.

Figure 4: House Price Changes by State (2002-2006)

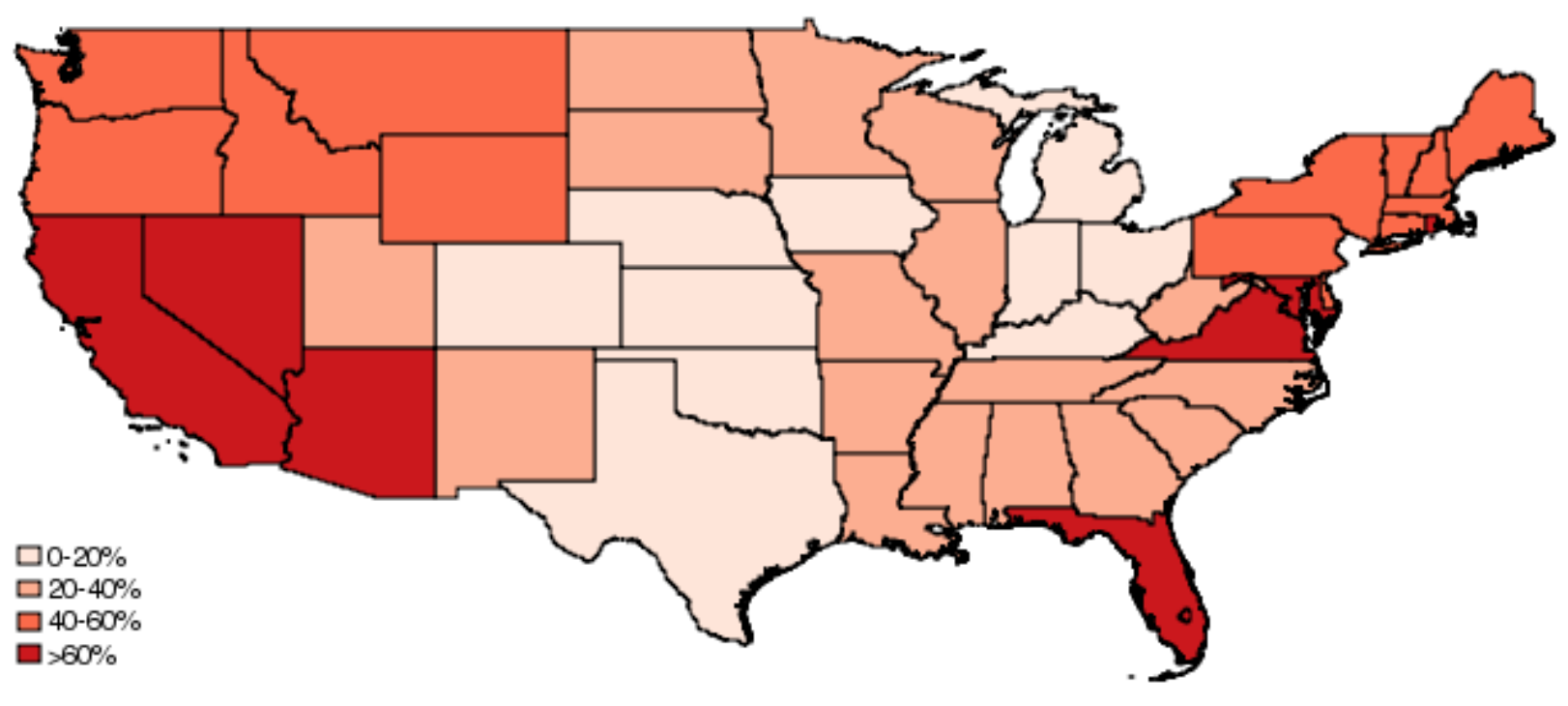

Source: FHFA/Haver Analytics. 